\title{
Solar Radiation Effect on the Complexation Capacity of Aquatic Humic Substances with Metals
}

\author{
Camila A. Melo, Ana L. De Toffoli, Altair B. Moreira and Márcia C. Bisinoti* \\ ${ }^{a}$ Departamento de Química e Ciências Ambientais, Instituto de Biociências, Letras e Ciências Exatas, \\ Universidade Estadual Paulista "Júlio de Mesquita Filho", Rua Cristóvão Colombo, 2265, \\ Jardim Nazareth, 15054-000 São José do Rio Preto-SP, Brazil
}

\begin{abstract}
Este estudo teve como principal objetivo avaliar o efeito da radiação solar sobre a capacidade de complexação das substâncias húmicas aquáticas (AHS) com as espécies metálicas $\mathrm{Al}^{3+}, \mathrm{Cr}^{3+}$, $\mathrm{CrO}_{4}{ }^{2-} \mathrm{e} \mathrm{Ni}^{2+}$. Microcosmos foram montados com AHS extraídas do Rio Preto com concentração de 5,0 $\mathrm{mg} \mathrm{L}^{-1}$ de carbono orgânico dissolvido e diferentes concentrações de metais, sendo expostos à radiação solar in situ. As constantes de estabilidade condicional foram de 2,0 $\times 10^{-2}, 1,1 \times 10^{-5} \mathrm{e}$ $2,6 \times 10^{-2}$ para os complexos AHS- $\mathrm{Cr}^{3+}$, AHS $-\mathrm{Ni}^{2+}$ e AHS $-\mathrm{CrO}_{4}{ }^{2-}$, respectivamente. Os resultados mostraram que a radiação solar foi responsável por um decréscimo na capacidade de complexação de $15-26 \%$ para AHS-Al ${ }^{3+}, 15-72 \%$ para AHS $-\mathrm{Cr}^{3+}, 12-18 \%$ para $\mathrm{AHS}-\mathrm{CrO}_{4}{ }^{2-}$ e de $13-42 \%$ para AHS- $\mathrm{Ni}^{2+}$. Conclui-se que a radiação solar altera a disponibilidade de metais previamente complexados às AHS, tornando-os disponíveis no corpo aquático.
\end{abstract}

This study had as main objective to assess the effect of solar radiation on the capacity of the aquatic humic substances (AHS) to complex $\mathrm{Al}^{3+}, \mathrm{Cr}^{3+}, \mathrm{CrO}_{4}{ }^{2-}$ and $\mathrm{Ni}^{2+}$. Microcosms were prepared with AHS from Preto River containing $5.0 \mathrm{mg} \mathrm{L}^{-1}$ of dissolved organic carbon and different concentrations of metal species, being exposed to solar radiation, in situ. Conditional stability constants obtained for the AHS- $\mathrm{Cr}^{3+}$, AHS- $\mathrm{Ni}^{2+}$ and $\mathrm{AHS}-\mathrm{CrO}_{4}{ }^{2-}$ complexes were $2.0 \times 10^{-2}$, $1.1 \times 10^{-5}$ and $2.6 \times 10^{-2}$, respectively. The results showed that solar radiation is responsible for decreasing capacity complexation in $15-26 \%$ for $\mathrm{AHS}-\mathrm{Al}^{3+}, 15-72 \%$ for $\mathrm{AHS}-\mathrm{Cr}^{3+}, 12-18 \%$ for $\mathrm{AHS}-\mathrm{CrO}_{4}{ }^{2-}$ and $13-42 \%$ for $\mathrm{AHS}-\mathrm{Ni}^{2+}$. We can conclude that solar radiation alters metals' availability previously complexed to AHS, making them available in the aquatic body.

Keywords: aquatic humic substances, metal complexation, solar radiation, fluorescence

\section{Introduction}

Aquatic humic substances (AHS) have been intensively studied because they play an essential role in biogeochemical processes. ${ }^{1,2}$ They can participate in the complexation reactions with metal ions thereby influencing the transport and availability of them in the environment, ${ }^{2-4}$ may suffer interactions with organic compounds and thus, reduce or increase its toxicity to the biota, ${ }^{4,5}$ can act in redox ${ }^{6}$ and photochemical reactions. ${ }^{7}$

Aquatic HS are products of the decomposition of vegetal and animal remains from microbiological transformations. They are normally dark colored organic macromolecules with a high molecular weight, a complex structure consisting of aromatic and aliphatic

*e-mail: bisinoti@ibilce.unesp.br compounds, which have a large number of functional groups containing oxygen, e.g., carboxylates $(-\mathrm{COOH})$, phenolics (aromatics- $\mathrm{OH})$, alcoholics $(-\mathrm{OH})$, quinones (aromatics $=\mathrm{O}$ ), among others. ${ }^{1,2}$ Depending on the water solubility, AHS can be operationally separated into three fractions: fulvic acids that are soluble in all $\mathrm{pH}$ range, humic acids that are soluble in alkaline $\mathrm{pH}$ and insoluble in acid $\mathrm{pH}$, and humin that is insoluble in all $\mathrm{pH}$ range. It is worth noting that the AHS comprise about $40-60 \%$ of the dissolved organic carbon (DOC) in aquatic environments ${ }^{2}$ and, due to the heterogeneity of pre-existing materials in the water bodies, the composition of AHS varies from one to another environment according to the source of organic matter, $\mathrm{pH}$, temperature and weather conditions like rainfall and mainly to the photochemical processes. ${ }^{8,9}$

The ability of AHS in complexing metal species is due to aromatic and aliphatic groups, which contains 
oxygen atoms responsible for the interactions with cationic species such as metals. ${ }^{10}$ Studies have covered the AHS complexation with different metals under different $\mathrm{pH}$ conditions, ionic strength and concentration of metals and AHS. ${ }^{11-15}$ A recent study demonstrated that solar radiation can also be an important factor in the complexation capacity of AHS with metals. ${ }^{8}, 16$ These authors showed that radiation alters the complexation capacity that the AHS had when not exposed to radiation previously. ${ }^{16-19}$ The role of solar radiation on the complexation capacity is not well understood mainly in tropical regions of the world where solar radiation is intense. Most studies dealing with the capacity complexation of AHS are made with $\mathrm{Cu}^{2+}$. On the other hand, so far metals such as $\mathrm{Al}, \mathrm{Cr}$ and $\mathrm{Ni}$ are poorly studied despite their environmental relevance.

Studies of the complexation capacity of AHS can be made using various analytical techniques such as polarography, voltammetry, ion selective electrode, ultrafiltration and molecular fluorescence. ${ }^{20-22}$ Among them molecular fluorescence has been one of the techniques used in many works to characterize AHS, ${ }^{23-26}$ as well as studies of complexation with metal ions..$^{27-29}$ The fluorescence has advantages over others, such as nuclear magnetic resonance (NMR) which is also widely used in AHS studies. ${ }^{30-32}$ Using fluorescence is possible to work with liquid samples and thus eliminating physical and chemical treatments which could alter AHS structure, and also enables the use of small samples, as well as having good sensitivity, robustness and its low cost. The fluorescence analysis of humic substances generate information about the structure, conformation and heterogeneity. ${ }^{33,34}$ The fluorescence excitationemission matrix (EEM) is a tool that allows to obtain better information on the existence of fluorophores and consequently on the chemical structure of AHS. ${ }^{35}$

Several authors have demonstrated that metals are responsible to quench the fluorescence signal, ${ }^{36-38}$ but in some cases it is possible to increase it. ${ }^{39}$ In cases of quenching of the fluorescence signals is possible to determine the conditional stability constant $\left(\mathrm{K}_{\mathrm{C}}\right)$ of AHS-metal complex using the Stern-Volmer model..$^{40-43}$ The $\mathrm{K}_{\mathrm{C}}$ provides information as to whether or not favoring the formation of AHS-metal complex, where higher values indicate $\mathrm{K}_{\mathrm{C}}$ favoring the complexation of metals in AHS. The Stern-Volmer model allows the calculation of $\mathrm{K}_{\mathrm{C}}$ from experiments where the metals are being gradually added to the AHS and the fluorescence signal is begin followed after each addition. Due to the aforementioned, the goal of this work is to evaluate the effect of solar radiation in the complexation capacity of AHS with metals species, such as $\mathrm{Al}^{3+}, \mathrm{Cr}^{3+}, \mathrm{CrO}_{4}{ }^{2-}$ and $\mathrm{Ni}^{2+}$.

\section{Experimental}

\section{Collecting water samples and isolation AHS}

Water samples were collected during rainy season from Preto River, São José do Rio Preto city, São Paulo state, Brazil, S $20^{\circ} 48^{\prime} 29.2^{\prime \prime}$ and W 049 22' 24.1" (Figure 1). The aquatic body chosen in this research is employed for public water supply and it has been considered in previous works, ${ }^{36}$ where AHS from rainy season show higher capacity complexation with metals. The water in this region is tropical hot, with rainy summers and temperatures of about $27^{\circ} \mathrm{C}$.

Nearly $400 \mathrm{~L}$ of water samples were collected using larger flasks pre-cleaned and acclimatized with water from the river $30 \mathrm{~cm}$ below the surface. Temperature, $\mathrm{pH}$, conductivity, turbidity and dissolved oxygen were measured in situ using multiparameter equipment previously calibrated in the laboratory and, when necessary, in field (Hanna, HI991300 and Hanna, HI9146-04, Romania). Water samples were filtered in qualitative paper for the removal of small branches and leaves and the $\mathrm{pH}$ was adjusted to approximately 2 with $6 \mathrm{~mol} \mathrm{~L}^{-1} \mathrm{HCl}$. AHS extraction were made using the method suggested by the International Humic Substances Society (IHSS). ${ }^{44}$ The $\mathrm{pH}$ was adjusted to the original $6.8 \mathrm{pH}$ of the sample with $1.0 \mathrm{~mol} \mathrm{~L}^{-1} \mathrm{HCl}$.

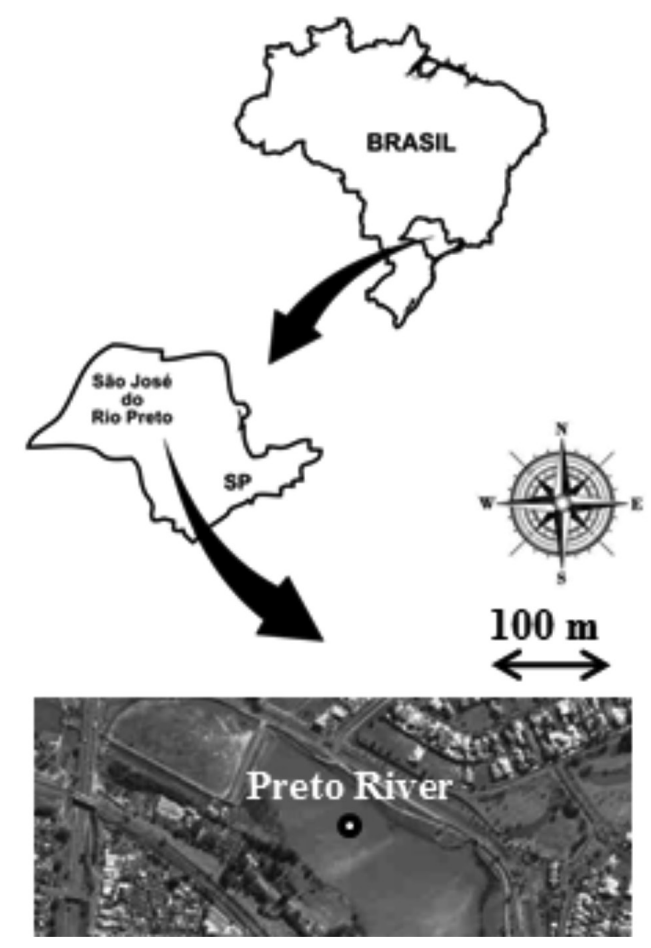

Figure 1. Map of the sample site, Preto River, São José do Rio Preto, São Paulo State, Brazil. 


\section{Molecular fluorescence measurements}

All fluorescence measurements were made using a spectrofluorimeter (Varian, Cary Eclipse, Australia) equipped with Xe lamp. In the experiments of complexation capacity the fluorescence spectra were obtained in two measurement modes: emission mode and synchronous mode. In both modes, a pre-scan of AHS sample was previously done, which indicated the best excitation wavelength. Emission mode was scanned from 350 to $650 \mathrm{~nm}$ with an excitation wavelength fixed at $332 \mathrm{~nm}$. Synchronous mode spectra were obtained from 240 to $700 \mathrm{~nm}$ using a wavelength interval of $18 \mathrm{~nm}$. All spectra were obtained with slits set at a $10 \mathrm{~nm}$ bandwidth and measurements were performed in triplicate. In the experiments that evaluated the effect of solar radiation on the complexation capacity, the fluorescence spectra were obtained only in emission mode from 350 to $650 \mathrm{~nm}$ with excitation fixed at $332 \mathrm{~nm}$ and slit of $10 \mathrm{~nm}$ bandwidth. For the AHS sample extracted from Preto River was made fluorescence spectra in emission and synchronous modes and also in excitation-emission matrix (EEM) mode. In this EEM, the spectra was obtained by colleting a series of scans, 400-600 nm for emission and 300-500 nm for excitation in increments of $5 \mathrm{~nm} .^{24}$

\section{Quantification of dissolved organic carbon (DOC)}

Dissolved organic carbon was measured using a total organic carbon analyzer (Shimadzu, TOC-VCSN, Japan) after filtering the water samples.

\section{AHS-metal complexation capacity and determination of the} conditional stability constant $\left(\mathrm{K}_{\mathrm{C}}\right)$

Complexation capacity studies were made individually with $\mathrm{Al}^{3+}, \mathrm{Cr}^{3+}, \mathrm{CrO}_{4}{ }^{2-}$ and $\mathrm{Ni}^{2+}$ metal ions. The metal solutions were prepared using reagents from pure analytical grade $\left(\mathrm{AlCl}_{3} \cdot 6 \mathrm{H}_{2} \mathrm{O}, \mathrm{NiCl}_{2} \cdot 6 \mathrm{H}_{2} \mathrm{O}\right.$ and $\mathrm{K}_{2} \mathrm{CrO}_{4}$ from Synth, Diadema, Brazil; $\mathrm{CrCl}_{3} \cdot 6 \mathrm{H}_{2} \mathrm{O}$, from Sigma/Aldrich) in ultrapure water (Millipore, Direct-Q, France). First, an experiment was done to evaluate the equilibrium time to reach complexation capacity of metals and AHS. So, $50.0 \mathrm{~mL}$ of AHS containing $5.0 \mathrm{mg} \mathrm{L}^{-1}$ of DOC was transferred to a magnetically stirred beaker with an aliquot of metal for a pre-determined period of time, being fluorescence signals in the emission and synchronous mode obtained for all samples. DOC concentration of $5.0 \mathrm{mg} \mathrm{L}^{-1}$ was chosen based on the DOC found in the Preto River $\left(3.3 \mathrm{mg} \mathrm{L}^{-1}\right)$ and previous study made in laboratory about complexation capacity. ${ }^{45}$ The equilibrium time was determined when any changes in the fluorescence signal would be observed (30 min for $\mathrm{Al}^{3+}$ and $20 \mathrm{~min}$ for the other ions).

Complexation capacity studies were made with $50.0 \mathrm{~mL}$ of AHS containing $5.0 \mathrm{mg} \mathrm{L}^{-1}$ of DOC, kept on agitation, followed by the addition of known metal concentrations. Fluorescence signals in the emission and synchronous mode were measured after each metal addition. The addition of metals was only stopped when the fluorescence signal was stabilized. The $\mathrm{pH}$ was always maintained at about 6.0 and 7.0 to avoid precipitation of metals. Analysis of the coagulation process for each metal studied was evaluated employing a program for chemical simulation equilibrium (CHEAQS Pro), ${ }^{46}$ which varied according to the composition of the samples.

In all experiments with metal addition where a quenching of the fluorescence signal was observed, conditional stability constants were calculated according to the Stern-Volmer model. ${ }^{41}$ In this model, a graph of $1 /$ Metal versus Io/ $\Delta \mathrm{I}$ was constructed where Io is the fluorescence intensity of the ligand when no metal is present and $\Delta \mathrm{I}$ the initial fluorescence fraction which corresponds to the available fluorescent structure for complexation $(\Delta \mathrm{I}=\mathrm{Io}-\mathrm{I}$, where $\mathrm{I}=$ fluorescence intensity of the ligand due to added metal) and from the linearity of the graph (equation 1$)$, the angular coefficient values $\left(1 / \mathrm{f}_{\mathrm{C}}\right)$ and linear coefficient (1/f) were used to determine $\mathrm{K}_{\mathrm{C}}$.

$\frac{\text { Io }}{\Delta \mathrm{I}}=\frac{1}{\mathrm{f}}+\frac{1}{\left(\mathrm{fK}_{\mathrm{C}}[\mathrm{M}]\right)}$

\section{Solar radiation effect on the complexation capacity of AHS}

The effect of solar radiation on the complexation capacity of $\mathrm{Al}^{3+}, \mathrm{Cr}^{3+}, \mathrm{CrO}_{4}{ }^{2-}$ and $\mathrm{Ni}^{2+}$ metals was assessed with microcosm experiments. These experiments were made by exposing samples containing $5.0 \mathrm{mg} \mathrm{DOC} \mathrm{L}^{-1} \mathrm{AHS}$ and different concentrations of metals as a strategy to maintain the same conditions of temperature and solar radiation intensity that occurs in the aquatic body. Polyethylene terephthalate (PET) bottles were filled up with AHS and metals and they submerged at a depth of approximately 30 $\mathrm{cm}$ in the Preto River waters. A control group was kept in the laboratory (not exposed to radiation) plus two groups in the field exposed to solar radiation under light conditions (exposed in the field to solar radiation) and under dark conditions (exposed in the field but with the whole bottle wrapped in aluminum foil). A group containing only AHS with $5.0 \mathrm{mg} \mathrm{L}^{-1}$ of DOC without metals was also kept under each of the laboratory and field conditions (light and dark). The concentrations of metals used in field experiments were 
those previously tested in laboratory in the experiments to assess the complexation capacity of same AHS. A total of 40 samples containing AHS with $5.0 \mathrm{mg} \mathrm{L}^{-1}$ of DOC received known concentrations of each metal, being $0.4,1.6$ and $5.9 \mathrm{mg} \mathrm{L}^{-1}$ for $\mathrm{Al}^{3+}, 5.9,13.7$ and $43.7 \mathrm{mg} \mathrm{L}^{-1}$ for $\mathrm{Cr}^{3+}$, 5.9 and $43.7 \mathrm{mg} \mathrm{L}^{-1}$ for $\mathrm{CrO}_{4}{ }^{2-}$ and $0.5,17.7$ and $377.4 \mathrm{mg} \mathrm{L}^{-1}$ for $\mathrm{Ni}^{2+}$. All these samples were kept in laboratory and field conditions under light and dark conditions.

At zero, 5 and $10 \mathrm{~h}$ of solar exposition (8:00 a.m., 1:05 p.m. and 6:15 p.m. respectively), the samples of each group were collected in field and transported to the laboratory conditioned in polyethylene boxes with ice. The distance from the locality in the field where the samples were exposed to the laboratory is $2 \mathrm{~km}$, a trip made by car in $5 \mathrm{~min}$. In the laboratory, the fluorescence spectra were obtained in emission mode as described previously.

A spectrum scan of UV-Vis at wavelengths of 200 and $800 \mathrm{~nm}$ of the PET bottle contents was obtained using a UV-Vis spectrophotometer. Water temperature was monitored using a thermometer.

\section{Results and Discussion}

The Preto River waters show quality where values found were $\mathrm{pH} 6.8$, temperature $27.0^{\circ} \mathrm{C}$, dissolved oxygen $7.2 \mathrm{mg} \mathrm{L}^{-1}$, conductivity $40.0 \mu \mathrm{S} \mathrm{cm}^{-1}$, dissolved organic carbon $3.3 \mathrm{mg} \mathrm{L}^{-1}$ and turbidity $13.1 \mathrm{FTU}$.

\section{Fluorescence spectra}

Molecular fluorescence spectra obtained in emission and synchronous modes from AHS extracted from the Preto River, shows a maximum fluorescence signal at $436 \mathrm{~nm}$ in the emission spectrum (Figure 2a), which indicates the predominant structure of aliphatic compounds. ${ }^{30}$ In the synchronous mode (Figure $2 \mathrm{~b}$ ), a maximum fluorescence intensity was observed in the range of 390-430 nm, being associated to aromatic polycyclic hydrocarbon having five conjugated rings, as well as fulvic acids. ${ }^{30,47}$ EEM spectrum (Figure 2c) shows a maximum fluorescence intensity in $\lambda_{\text {exc }} / \lambda_{\text {emi }} 250 / 425 \mathrm{~nm}$ and in $\lambda_{\text {exc }} / \lambda_{\text {emi }} 340 / 430 \mathrm{~nm}$, which correspond to fulvic and humic acids, respectively, according to the literature..$^{25,48,49}$ It stands out that maximum fluorescence intensity in $\lambda_{\text {exc }} / \lambda_{\text {emi }} 250 / 425 \mathrm{~nm}$ attributed to fulvic acids have a greater intensity. Therefore, it can be verified that AHS extracted from the Preto River waters have the characteristics of a recently degraded organic matter due to a predominance of aliphatic compounds in their structure, as seen from the spectra. These results are in agreement with the period of AHS isolation.
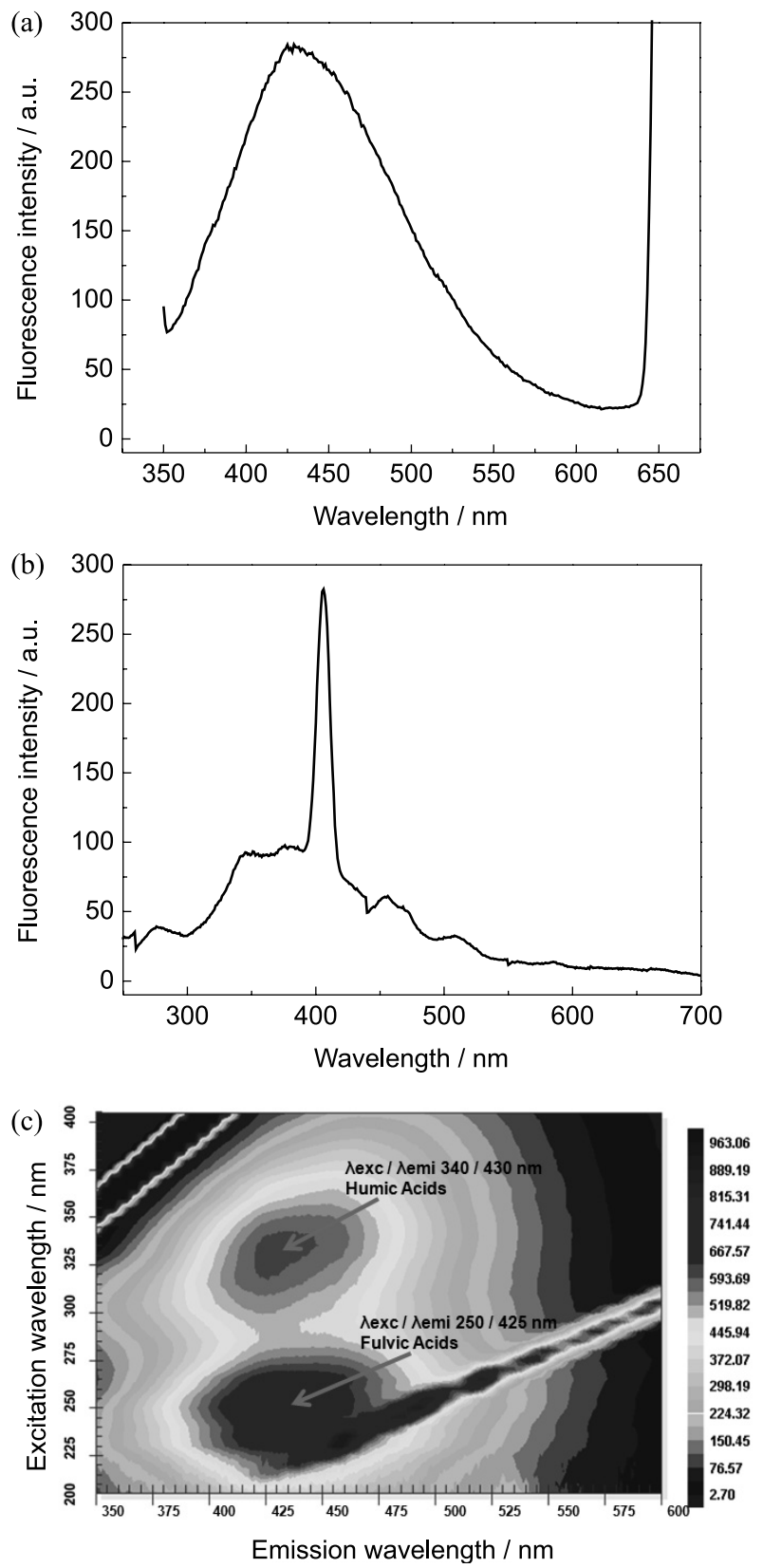

Figure 2. Fluorescence spectra in the emission (a), synchronous (b) and excitation-emission matrix (EEM) (c) modes for the AHS extracted from the Preto River waters.

Complexation capacity of AHS from the Preto River with $\mathrm{Al}^{3+}, \mathrm{Cr}^{3+}, \mathrm{CrO}_{4}{ }^{2-}$ and $\mathrm{Ni}^{2+}$

AHS are compounds that have the capacity of emitting fluorescence when excited by electromagnetic radiation due to their organic composition with conjugated aromatic rings. The AHS interaction with metal species cause, frequently, a quenching of initial fluorescence intensity. ${ }^{37,38}$ With some metals this interaction can also promote an increase of fluorescence signal, as noted for aluminum. ${ }^{39}$ Complexation capacity studies made in this work showed 

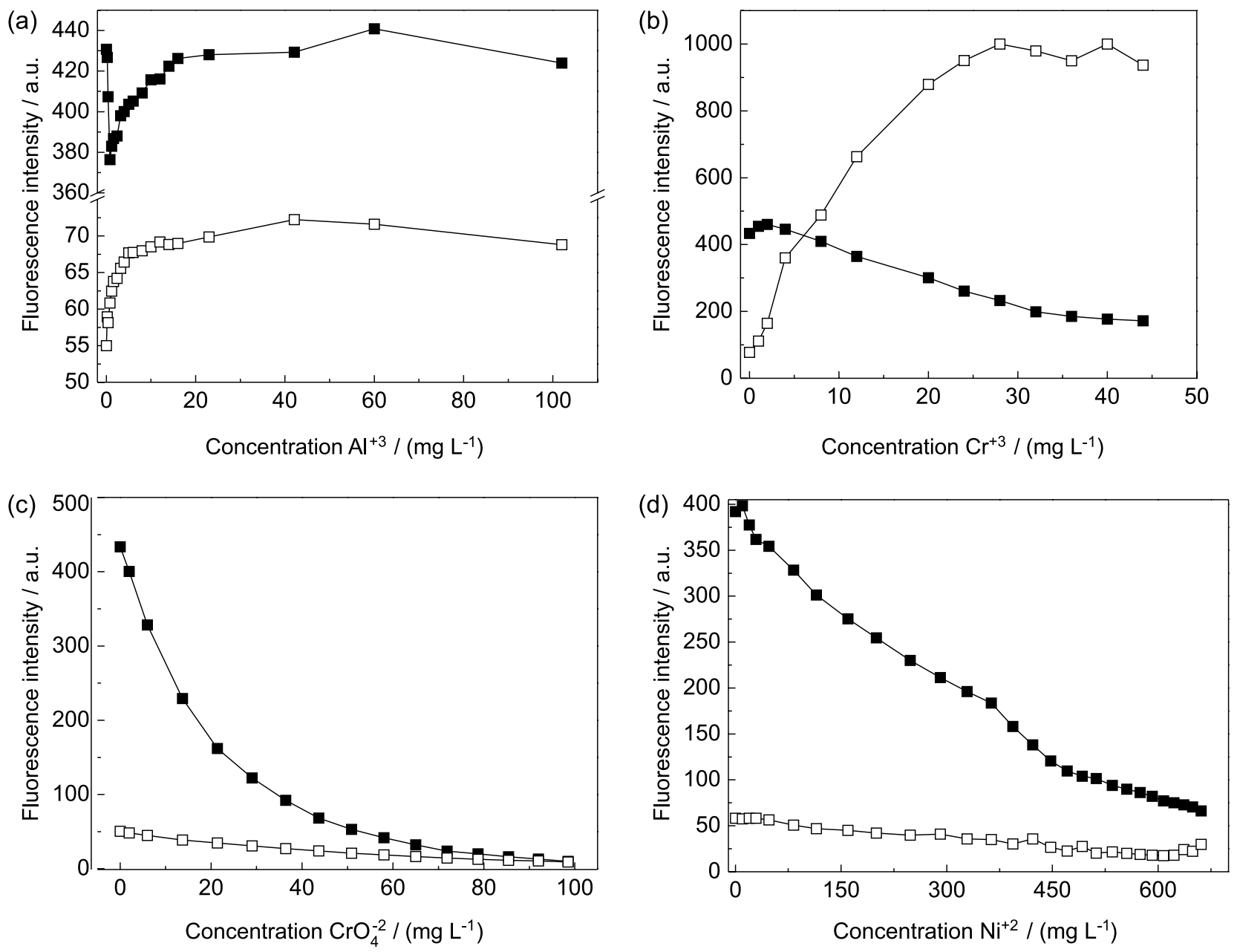

Figure 3. Fluorescence maximum intensity curves obtained in the modes emission ( $\square$ ) and synchronized ( $\square$ ) for the AHS- $\mathrm{Al}^{3+}$ (a), AHS-Cr ${ }^{3+}$ (b), AHS $-\mathrm{CrO}_{4}{ }^{2-}(\mathrm{c})$ and $\mathrm{AHS}-\mathrm{Ni}^{2+}(\mathrm{d})$ complexes.

that fluorescence intensity grows with an increase of the quantities of $\mathrm{Al}^{3+}$. On the other hand, when adding $\mathrm{Cr}^{3+}$, $\mathrm{CrO}_{4}{ }^{2-}$ and $\mathrm{Ni}^{2+}$, there was a quenching of fluorescence intensity. This behavior is shown in Figures 3a, 3b, 3c, and $3 \mathrm{~d}$.

The first fact that should be observed is that with the first additions of $\mathrm{Al}^{3+}$, the emission mode fluorescence intensity decreased. Adding more $\mathrm{Al}^{3+}$, the fluorescence signal increased until it stabilized where further additions had no effect. A similar fluorescence increase behavior was observed with spectra obtained in the synchronous mode. Sharpless and $\mathrm{McGown}^{39}$ found similar behavior when assessing the complexation capacity of $\mathrm{Al}^{3+}$ with humic substance of aquatic source. According to these authors, ${ }^{39}$ a decrease in intensity of the fluorescence signal with metal addition is common when humic substances are of terrestrial origin. Another fact that is worth mentioning is that the maximum emission fluorescence signal $(431 \mathrm{~nm}$ for AHS without metal addition) is a bit shifted towards lower wavelengths $(422 \mathrm{~nm})$ in the emission spectrum. Elkins and Nelson ${ }^{27}$ observed a $142 \%$ increase of the emission fluorescence intensity when $\mathrm{Al}^{3+}$ was added to the fulvic acid extracted from a river. These authors also evidenced a shift in the emission wavelength from 440 to $424 \mathrm{~nm}$, and the excitation wavelength from 324 to $344 \mathrm{~nm}$. These shifts were associated to a strong $\mathrm{Al}^{3+}$ interaction and high density charge which ends up significantly altering the electronic structure of the fulvic acid. In the synchronous spectrum, the maximum fluorescence signals where intensity increased referred to wavelengths of 366 and $406 \mathrm{~nm}$, where 5 aromatic ring compounds can be present. Stability of the AHS- $\mathrm{Al}^{3+}$ complex was reached when final concentration reached $20 \mathrm{mg} \mathrm{L}^{-1}$ of $\mathrm{Al}^{3+}$ (Figure 3a). According to the results obtained employing CHEAQS Pro, from 70 to $91 \%$ of $\mathrm{Al}^{3+}$ is complexed with organic matter in the concentrations employed. Other species in low concentrations are present, such as $\left[\mathrm{Al}(\mathrm{OH})_{2}\right]^{+}, \mathrm{Al}(\mathrm{OH})_{3(\text { aq) }}$ and $\left[\mathrm{Al}(\mathrm{OH})_{4}\right]^{-}$.

No fluorescence signal shift was observed with $\mathrm{CrO}_{4}{ }^{2-}$ for lower or higher wavelengths, with the maximum emission spectrum fluorescence signal occurring at $429 \mathrm{~nm}$. 
In the synchronous spectrum there were three maxima fluorescence signals at 280, 368 and $406 \mathrm{~nm}$. It should be noted that maximum fluorescence intensities at 280 and $368 \mathrm{~nm}$ gradually decrease with the addition of metal until a near total quenching, suggesting that $\mathrm{CrO}_{4}{ }^{2-}$ must first act on compounds of the aromatic amino acid type and volatile acids of aliphatic structure $(280 \mathrm{~nm})$, followed by those with chromophores groups that have from 3 to 4 conjugated aromatic rings $(368 \mathrm{~nm})$. Stability of the AHS- $\mathrm{CrO}_{4}{ }^{2-}$ complex was reached when a quantity close to $90.0 \mathrm{mg} \mathrm{L}^{-1}$ of $\mathrm{CrO}_{4}{ }^{2-}$ was added (Figure $3 \mathrm{c}$ ).

In studies with $\mathrm{Cr}^{3+}$, a slight increase of the fluorescence intensity in the emission mode at $429 \mathrm{~nm}$ can be first seen and afterwards a gradual decrease followed by stability. In the synchronous mode, an increase of the fluorescence intensity was observed at a wavelength of $406 \mathrm{~nm}$. Stability of the AHS- $\mathrm{Cr}^{3+}$ complex was reached when $32.0 \mathrm{mg} \mathrm{L}^{-1}$ of $\mathrm{Cr}^{3+}$ was added.

No wavelength shifts in the spectra were observed with $\mathrm{Ni}^{2+}$. A quenching of fluorescence with the addition of $\mathrm{Ni}^{2+}$ was observed in both emission and synchronous spectra. Three maximum fluorescence signals were seen in the synchronous spectrum, one at $280 \mathrm{~nm}$, other at $364 \mathrm{~nm}$ and the last one at $405 \mathrm{~nm}$. As discussed previously, the fluorescence signal at $364 \mathrm{~nm}$ is in a region where there are 3 to 4 aromatic ring structures, and the signal at $405 \mathrm{~nm}$ corresponds to 5 aromatic rings. ${ }^{24}$ It was observed that similarly to $\mathrm{CrO}_{4}{ }^{2-}$ ion the fluorescence signal at $280 \mathrm{~nm}$ was quenched with the addition of $\mathrm{Ni}^{2+}$. Stability of the AHS- $\mathrm{Ni}^{2+}$ complex was reached when close to $600.0 \mathrm{mg} \mathrm{L}^{-1}$ of $\mathrm{Ni}^{2+}$ was added (Figure $3 \mathrm{~d}$ ).

The calculation to find the conditional stability constant $\left(\mathrm{K}_{\mathrm{C}}\right)$ cannot be applied to the AHS-Al ${ }^{3+}$ complex because the Stern-Volmer model is only applicable when the fluorescence signal is quenched. The knowledge of the conditional stability constant is intimately related to the formation stability of the AHS-metal complex and, consequently, to its important role in the sequestration and maintenance of the availability of the metal. Conditional stability constants were calculated by applying the Stern-Volmer model to the AHS- $\mathrm{CrO}_{4}{ }^{2-}, \mathrm{AHS}-\mathrm{Ni}^{2+}$ and AHS- $\mathrm{Cr}^{3+}$ complexes for emission mode spectra. Table 1 shows the linear regression coefficient values for the complexes and the conditional stability constant values.

Note that the AHS $-\mathrm{Ni}^{2+}$ complex shows a lower conditional stability constant value, which allows the inference that this complex is the most unstable and the metal is more liable for to be uncomplexed from the AHS structure and, therefore, become more available in an aquatic environment. These results are in agreement with values previously obtained employing CHEAQS Pro, ${ }^{46}$
Table 1. Linear regression coefficient values for linearity curves obtained from Stern-Volmer model for the AHS- $\mathrm{CrO}_{4}{ }^{2-}, \mathrm{AHS}-\mathrm{Ni}^{2+}$ and AHS- $\mathrm{Cr}^{3+}$ complexes and conditional stability constant values

\begin{tabular}{lcc}
\hline Complex & $\mathrm{R}^{2}$ & $\mathrm{~K}_{\mathrm{C}}$ \\
\hline $\mathrm{AHS}-\mathrm{CrO}_{4}{ }^{2-}$ & 0.99 & $2.610^{-2}$ \\
$\mathrm{AHS}-\mathrm{Ni}^{2+}$ & 0.99 & $1.110^{-5}$ \\
$\mathrm{AHS}-\mathrm{Cr}^{3+}$ & 0.99 & $2.010^{-2}$ \\
\hline
\end{tabular}

where around $99 \%$ of $\mathrm{Ni}^{2+}$ is present in free form not bound to organic nor inorganic compounds. Similar results were found by Silva et al. ${ }^{12}$

Regarding to chromium complexes, no statistical differences $(\mathrm{p}=0.05)$ between the complexes AHS $-\mathrm{Cr}^{3+}$ and $\mathrm{AHS}-\mathrm{CrO}_{4}{ }^{2-}$ were observed. One hypothesis to explain this behavior can be associated with the capacity of AHS to reduce metals or the increase of semiquinones radicals' generation by radiation. For the first case AHS could reduce $\mathrm{Cr}(\mathrm{VI})$ to $\mathrm{Cr}(\mathrm{III})$ form and subsequently complex the reduced form. Romão et al. ${ }^{50}$ demonstrated that AHS can reduce $\mathrm{Cr}(\mathrm{VI})$ in acid $\mathrm{pH}$ (2.5), being that this behavior was not observed for $\mathrm{pH}$ 6.0. Probably this mechanism can be disregarded for this work. Similar $\mathrm{K}_{\mathrm{C}}$ results were found by Merdy et al. ${ }^{51}$

\section{Solar radiation effect on the complexation capacity of AHS}

Some studies have already shown that solar radiation is able to degrade natural organic matter ${ }^{19,48}$ and to interfere in the interaction of these metal species. However, few studies with the same AHS thematic have been addressed in the literature. Experiments performed in this work were carried out simulating the environmental conditions of an aquatic body during the day, such as exposure to solar radiation, temperature and movement, among others. PET bottles containing the AHS and metal ion species were taken to the field where they remained under the same conditions of the aquatic body. An absorbance spectrum of the PET bottle material was obtained and it was noted that the PET bottle absorbed wavelengths below $330 \mathrm{~nm}$, allowing the passage of visible radiation.

During the experiment, parameters such as water temperature and ultraviolet radiation intensity were monitored. Water temperature was taken at 8:00 a.m. $\left(24{ }^{\circ} \mathrm{C}\right)$ when the bottles were placed in the waters. Temperature was again monitored at 1:05 p.m. $\left(29^{\circ} \mathrm{C}\right)$ when a group of samples were withdrawn, and again at 6:15 p.m. $\left(30^{\circ} \mathrm{C}\right)$ when remaining bottles were withdrawn.

A control for each experiment was kept in the laboratory for comparative purposes. AHS without metal additions were exposed in the field under light and dark 
conditions, as it was made with the control in the laboratory. Figures $4 \mathrm{a}$ and $4 \mathrm{~b}$ have the emission and synchronous fluorescence spectra which show the behavior of AHS without metal ion addition. It may be seen that for the AHS samples exposed to solar radiation there was a decreased fluorescence intensity of $13 \%$ (emission mode) after a $10 \mathrm{~h}$ exposition. No significant differences were observed between laboratory control samples and those kept under dark conditions in the field $(\mathrm{p}=0.05)$, as was expected (Figure 4a). This result confirms that observed alterations must be attributed to solar radiation. These results were considered for the experiments of effect of solar radiation in the complexation capacity with metals. In the synchronous mode (Figure 4b), the same behavior was observed, a decreased fluorescence intensity of $16 \%$ for samples kept under light conditions. AHS DOC concentrations kept under light (7.41 $\left.\mathrm{mg} \mathrm{L}^{-1}\right)$ and dark $\left(7.45 \mathrm{mg} \mathrm{L}^{-1}\right)$ conditions were also monitored, with no difference $(p=0.05)$ being observed during the exposition to solar radiation.

A decrease of fluorescence intensity due to exposure to natural or artificial radiation was observed by other authors by dissolved organic matter. ${ }^{19,49,52}$ Gonsior et al. ${ }^{19}$ verified a fluorescence intensity reduction of $24 \%$ for the Preto River water, in California, and verified a greater degradation in compounds that contain fluorescent chromophore groups. They also observed that a concentration of DOC remained constant during radiation. On the other hand, in a laboratory experiment with natural radiation, ${ }^{52}$ it was verified that DOC concentration decreased close to $70 \%$ for AHS extracted from Amazon River waters. An interesting fact is that for the more aromatic AHS there was a greater intensity loss which was attributed to a greater generation of free radicals, while for AHS with aliphatic characteristics degradation was lower, though faster. In this study, the AHS had predominantly aliphatic characteristics what can be associated to solar radiation exposed for 10 hours, resulting in a rapid AHS alteration.

A decrease of fluorescence intensity as exposure to solar radiation was also observed in the group with AHS and metals. Table 2 shows the fluorescence intensity values for $\mathrm{AHS}-\mathrm{Al}^{3+}$, $\mathrm{AHS}-\mathrm{Cr}^{3+}, \mathrm{AHS}-\mathrm{CrO}_{4}{ }^{2-}$ and $\mathrm{AHS}-\mathrm{Ni}^{2+}$ complexes according to the time exposed to solar radiation, as well as the observed percentages of decrease after discounting the decrease value of the AHS chromophores groups as presented in Figure 4 discussion.

A decrease of observed intensity for the different concentrations of the same AHS-metal group at $0 \mathrm{~h}$ (Table 2) is associated to the fact that the measurements were taken after the complexation time, which is necessary for the complex to stabilize (30 min for $\mathrm{Al}^{3+}$ and $20 \mathrm{~min}$ for the other ions). This explains why the maximum fluorescence intensity decreases as ion concentrations increase. Decrease percentages were calculated considering fluorescence intensities of the samples exposed for $10 \mathrm{~h}$ to solar radiation and the fluorescence intensities of samples exposed for $10 \mathrm{~h}$ to solar radiation under dark conditions. As it can be seen in Table 2, the groups exposed to solar radiation under dark conditions did not have significant losses of the maximum fluorescence intensity. This reinforces the observed behavior, enabling an association of intensity decrease to the effect of solar radiation.

Results showed in this work demonstrated that solar radiation decreased AHS-ion complexation capacity, identified by the fluorescence intensity decreases, making the metallic ions more available to be transported in the environment (Table 2). The differences between the decrease percentages were expected since each metal ion has distinctive characteristics such as load density,
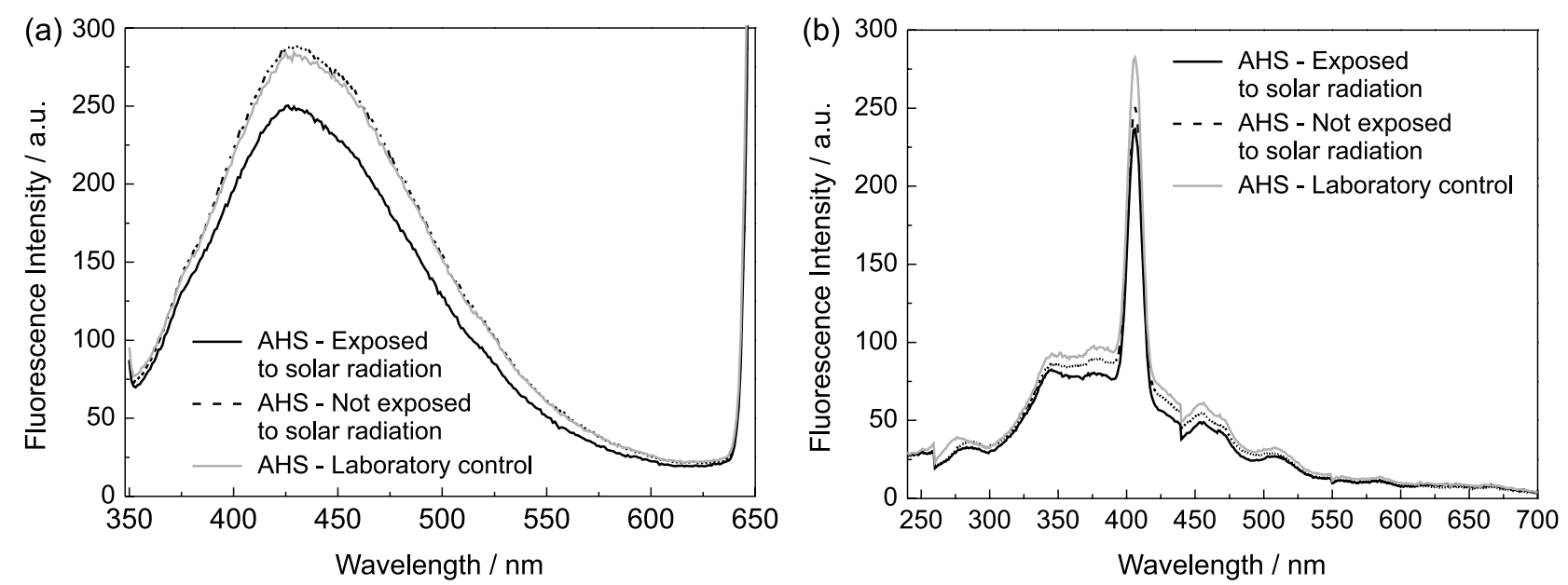

Figure 4. Fluorescence spectra in emission (a) and synchronous (b) modes for AHS (DOC of $5 \mathrm{mg} \mathrm{L}^{-1}$ ) samples exposed to light (clear conditions), not exposed to light (dark conditions) and laboratory control. 
Table 2. Fluorescence maximum intensity values obtained in $430 \mathrm{~nm}$, for AHS- $\mathrm{Al}^{3+}, \mathrm{AHS}-\mathrm{Cr}^{3+}, \mathrm{AHS}-\mathrm{CrO}_{4}{ }^{2-}$ and $\mathrm{AHS}-\mathrm{Ni}^{2+}$ complexes at different times of solar radiation exposition, decrease percentages due to radiation and the values of the group exposed to radiation in darkness

\begin{tabular}{|c|c|c|c|c|c|}
\hline \multirow{2}{*}{$\begin{array}{l}\text { Concentration / } \\
\left(\mathrm{mg} \mathrm{L}^{-1}\right)\end{array}$} & \multicolumn{3}{|c|}{ Exposed to radiation (in light) } & \multirow{2}{*}{$\begin{array}{c}\text { Percentages of } \\
\text { decrease } / \%\end{array}$} & \multirow{2}{*}{$\begin{array}{l}\text { Exposed to radiation } \\
\text { (in dark condition) }\end{array}$} \\
\hline & $0 \mathrm{~h}^{\mathrm{a}}$ & $5 \mathrm{~h}$ & $10 \mathrm{~h}$ & & \\
\hline \multicolumn{6}{|l|}{ AHS-Al ${ }^{3+}$} \\
\hline 0.4 & $294 \pm 1.5$ & $262 \pm 1.3$ & $250 \pm 1.3$ & 26 & $338 \pm 1.7$ \\
\hline 1.6 & $237 \pm 1.2$ & $240 \pm 1.2$ & $232 \pm 1.2$ & 15 & $272 \pm 1.4$ \\
\hline 5.9 & $151 \pm 0.8$ & $148 \pm 0.7$ & $137 \pm 0.7$ & 23 & $178 \pm 0.9$ \\
\hline \multicolumn{6}{|l|}{ AHS-Cr ${ }^{3+}$} \\
\hline 5.9 & $249 \pm 1.2$ & $\mathrm{~b}$ & $232 \pm 1.2$ & 15 & $274 \pm 1.4$ \\
\hline 13.7 & $171 \pm 0.9$ & $\mathrm{~b}$ & $42 \pm 0.2$ & 72 & $154 \pm 0.7$ \\
\hline 43.7 & $116 \pm 0.6$ & $\mathrm{~b}$ & $39 \pm 0.2$ & 63 & $104 \pm 0.5$ \\
\hline \multicolumn{6}{|l|}{ AHS-CrO ${ }_{4}^{2-}$} \\
\hline 5.9 & $235 \pm 1.2$ & $217 \pm 1.1$ & $187 \pm 0.9$ & 12 & $212 \pm 1.1$ \\
\hline 43.7 & $54 \pm 0.3$ & $48 \pm 0.2$ & $40 \pm 0.2$ & 18 & $49 \pm 0.2$ \\
\hline \multicolumn{6}{|l|}{ AHS-Ni' ${ }^{2+}$} \\
\hline 0.5 & $285 \pm 1.4$ & $259 \pm 1.3$ & $243 \pm 1.2$ & 13 & $280 \pm 1.4$ \\
\hline 17.7 & $246 \pm 1.2$ & $203 \pm 1.0$ & $120 \pm 0.6$ & 42 & $209 \pm 1.0$ \\
\hline 377.4 & $173 \pm 0.9$ & $157 \pm 0.8$ & $118 \pm 0.6$ & 29 & $167 \pm 0.8$ \\
\hline
\end{tabular}

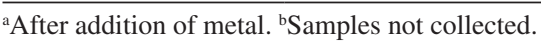

atomic radius, among others. Recent studies show an association of metals having a concentration of radical semiquinones. ${ }^{53}$ AHS exposed to solar radiation produce radical semiquinones. ${ }^{54} \mathrm{An}$ increase of the concentrations in radical semiquinones and hidroquinones causes a displacement of the metal ions of the humic substances structure, due to the greater formation of oxygen radicals which are reactive species in the structure. Decreases of fluorescence intensities are therefore expected as a greater formation of radical semiquinones due to the intensity of the solar radiation favors oxygen reactive species which act on the AHS structure, consequently on the complexation capacity of these with metallic ions. ${ }^{53}$ EPR measurements could prove if radical semiquinones were present as previously demonstrated by Jerzykiewicz et al. ${ }^{53}$ These authors observed a decrease of concentrations of radical semiquinones when $\mathrm{Ni}^{2+}$ and $\mathrm{Cu}^{2+}$ are present. On the other hand, metallic ions such as $\mathrm{Zn}^{2+}, \mathrm{Cd}^{2+}$ and other diamagnetic ions increase the effect of metal coordination by increasing the concentration of the radical semiquinones.

\section{Conclusions}

In this study it could first be verified that AHS extracted from the Preto River has the characteristics of recently degraded organic matter as proved by the presence of predominantly aliphatic structures and, therefore, with a low humification degree. Based on conditional stability constant values obtained for the AHS $-\mathrm{Cr}^{3+}$, AHS- $\mathrm{Ni}^{2+}$ and AHS- $\mathrm{CrO}_{4}{ }^{2-}$ complexes, it can be seen that AHS really come from an organic matter that does not have a good enough capacity to complex metallic ions efficiently, with $\mathrm{K}_{\mathrm{C}}$ values considered low. We can conclude that solar radiation affects the capacity of AHS to complex metallic ions, being observed a decrease of $15-26 \%$ for $\mathrm{AHS}-\mathrm{Al}^{3+}$, $15-72 \%$ for AHS- $-\mathrm{Cr}^{3+}, 12-18 \%$ for $\mathrm{AHS}-\mathrm{CrO}_{4}{ }^{2-}$ and $13-42 \%$ for $\mathrm{AHS}-\mathrm{Ni}^{2+}$. These results are important because they allow inferring that with an aquatic body the solar radiation enables ions to be more available which, consequently, could increase toxicity in an aquatic body. In conclusion, radiation effect will be more pronounced depending on the size and charge of each metallic ion, which will affect its susceptibility of binding to the active site (chromophores group) of the AHS structure.

\section{Acknowledgments}

This work was supported by grant and scholarship from Fundação de Amparo à Pesquisa do Estado de São Paulo (FAPESP). We would like to thank the two anonymous referees.

\section{References}

1. Hessen, D. O.; Tranvik, L. J.; Aquatic Humic Substances: Ecology and Biogeochemistry, $1^{\text {st }}$ ed.; Springer: New York, 1998.

2. Rocha, J. C.; Rosa, A. H.; Substâncias Húmicas Aquáticas: Interações com Espécies Metálicas, 1a. ed.; Unesp: São Paulo, Brasil, 2003.

3. Yang, R.; Van Den Berg, C. M. G.; Environ. Sci. Technol. 2009, 43, 7192. 
4. Yonebayashi, K.; Hattori, T.; Soil Sci. Plant Nutr.1988, 34, 571.

5. Rocha, J. C.; Rosa, A. H.; Cardoso, A. A.; Introdução à Química Ambiental, 1a. ed.; Bookman: Porto Alegre, Brasil, 2004.

6. Liu, T.; Tsang, D. C. W.; Lo, I. M. C.; Environ. Sci. Technol. 2008, 42, 2092.

7. Voelker, B. M.; Morel, F. M. M.; Sulzberger, B.; Environ. Sci. Technol. 1997, 31, 1004.

8. Danilov, R. A.; Ekelund, N. G. A.; Hidrobiologia 2001, 444, 203.

9. Esteves, V. I.; Otero, M.; Duarte, A. C.; Org. Geochem. 2009, 40, 942.

10. Evangelou, V. P.; Marsi, M.; Plant Soil 2001, 229, 13.

11. Chakraborty, P.; Chakrabarti, C. L.; Water, Air, Soil Pollut. 2008, 195, 63.

12. Silva, J. C. G. E.; Herrero, A. I.; Machado, A. A. S. C.; Barrado, E.; Microchim. Acta 1998, 130, 63.

13. Cao, J.; Lam, K. C.; Dawson, R. W.; Liu, W. X.; Tao, S.; Chemosphere 2004, 54, 507.

14. Provenzano, M. R.; Dórazio, V.; Jerzykiewicz, M.; Senesi, N.; Chemosphere 2004, 55, 885.

15. Christl, I.; Metzger, A.; Heidmann, I.; Kretzschmar, R.; Environ. Sci. Technol. 2005, 9, 5319.

16. Porcal, P.; Amirbahman, A.; Kopácek, J.; Novak, F.; Norton, S. A.; J. Environ. Monit. 2009, 11, 1064.

17. Dantas, B. F.; Pereira, M. S.; Ribeiro, L. de S.; Maia, J. L. T.; Bassoi, L. H.; Rev. Bras. Frutic. 2007, 29, 632.

18. Brooks, M. L.; Meyer, J. S.; McKnight, D. M.; Hydrobiology 2007, 579, 95.

19. Gonsior, M.; Peake, B. M., Cooper, W. T.; Podgorski, D., Dándrilli, J.; Cooper, W. J.; Environ. Sci. Technol. 2009, 43, 698.

20. Oliveira, L. C.; Ribeiro, C. A.; Rosa, A. H.; Botero, W. G.; Rocha, J. C.; Romão, L. P. C.; dos Santos, A.; J. Braz. Chem. Soc. 2009, 20, 1135.

21. Rocha, J. C.; Sargentini Jr, E.; Toscano, I. A. S.; Rosa, A. H.; Burba, P.; J. Braz. Chem. Soc. 1999, 10, 169.

22. Ryan, D. K.; Weber, J. H.; Anal. Chem. 1982, 54, 986.

23. Mobed, J. J.; Hemmingsen, S. L.; Autry, J. L.; McGown, L. B.; Environ. Sci. Technol. 1996, 30, 3061.

24. Peuravuori, J.; Koivikko, R.; Pihlaja, K.; Water Res. 2002, 36, 4552.

25. Sierra, M. M. D.; Giovanela, M.; Parlanti, E.; Soriano-Sierra, E. J.; Chemosphere 2005, 58, 715.

26. Birdwell, J. E.; Engel, A. S.; Org. Geochem. 2010, 41, 270.

27. Elkins, K. M.; Nelson, D. J.; J. Inorg. Biochem. 2001, 87, 81.

28. Fu, P.; Wu, F.; Liu, C.; Wang, F.; Li, W.; Yue, L.; Guo, Q.; Appl. Geochem. 2007, 22, 1668.

29. Elkins, K. M.; Nelson, D. J.; Coord. Chem. Rev. 2002, 228, 205.

30. Peuravuori, J.; Environ. Sci. Technol. 2005, 39, 5541.

31. Smejkolová, D.; Piccolo, A.; Environ. Sci. Technol. 2008, 42, 699.

32. Scapini, M. C.; Conzonno, V. H.; Balzaretti, V. T.; Cirelli, A. F.; Aquatic Sciences 2010, 72, 1.
33. Alberts, J. J.; Takács, M.; Org. Geochem. 2004, 35, 1141.

34. Azevedo, J. C. R.; Nozaki, J.; Quim. Nova 2008, 31, 1324.

35. Lombardi, A. T.; Jardim, W. F.; J. Braz. Chem. Soc. 1997, 8, 339.

36. Melo, C. A.; Campanha, M. B.; Ferrarese, R. F. M. S.; Tadini, A. M.; Yabe, M. J. S.; Moreira, A. B.; Bisinoti, M. C.; Sustainable Water Management on the Tropics and Subtropics, 3a. ed.; Jaguarão: Brasil, 2010, ch. 17.

37. Ryan, D. K.; Weber, J. H.; Anal. Chem. 1982, 54, 986.

38. Kumke, M. U.; Eidner, S.; Kruger, T.; Environ. Sci. Technol. 2005, 39, 9528.

39. Sharpless, C. M.; McGown, L. B.; Environ. Sci. Technol. 1999, 33, 3264.

40. Lakowicz, J. R.; Principles of Fluorescence Spectroscopy, $3^{\text {rd }}$ ed.; Springer: New York, 1999.

41. Tao, Z. Y.; Guo, Zh. J.; Dong. W. M.; J. Radioanal. Nucl. Chem. 2003, 256, 575 .

42. Dalzell, B. J.; Minor, E. C.; Mopper, K. M.; Org. Geochem. 2009, 40, 243.

43. Pinheiro, J. P.; Mota, A. M.; Simões Gonçalves, M. L.; Anal. Chim. Acta 1994, 284, 525.

44. Rosa, A. H.; Goveia, D.; Bellin, I. C.; Tonello, P. S.; Antunes, M. L. P.; Dias Filho, N. L.; Rodrigues Filho, U. P.; Quim. Nova 2007, 40, 59 .

45. Melo, C. A.; Dissertação de Mestrado, Universidade Estadual Paulista "Júlio de Mesquita Filho", Brasil, 2010.

46. http://home.tiscali.nl/cheaqs/ accessed in July 2012.

47. Ferrari, G. M.; Minazzini, M.; Mar. Ecol. Prog. Ser. 1995, 125, 305.

48. Tzortziou, M.; Osburn, C. L.; Neale, P. J.; Photochem. Photobiol. 2007, 83, 782.

49. Winter, A. R.; Fish, T. A. E.; Playle, R. C.; Smith, D. S.; Curtis, P. J.; Aquat. Toxicol. 2007, 84, 215.

50. Romão, L. P. C.; Araújo, A. B.; Rosa, A. H.; Rocha, J. C.; Eclét. Quím. 2002, 27, 383.

51. Merdy, P.; Gharbi, T. L.; Milori, D. M. P.; Ribeiro, R. A. S.; Lucas, Y.; Geoderma 2009, 150, 179.

52. Rodriguez-Zuniga, U. F.; Milori, D. M. B. P.; Silva, W. T. L.; Martin-Neto, L.; Oliveira, L. C.; Rocha, J. C.; Environ. Sci. Technol. 2008, 42, 1948.

53. Jerzykiewicz, M.; Jezierski, A.; Czechawski, F.; Drozs, J.; Org. Geochem. 2002, 33, 265

54. Paul, A.; Stosser, R.; Zehl, A.; Zwirnmann, E.; Vogt, R. D.; Steinberg, C. E. W.; Environ. Sci. Technol. 2006, 40, 5897.

Submitted: April 23, 2012

Published online: October 19, 2012

FAPESP has sponsored the publication of this article. 